\title{
EKOLOGI SASTRA PADA PUISI DALAM NOVEL BAPANGKU BAPUNKKU KARYA PAGO HARDIAN
}

\author{
Mardiana Sari \\ Dosen Universitas PGRI Palembang \\ marsharifadiana@gmail.com
}

\begin{abstract}
ABSTRAK
Karya sastra diciptakan untuk dinikmati, dirasakan dan dimanfaatkan oleh pembaca ataupun penikmat sastra. Proses penciptaan sastra tidak luput dari lingkungan sekitar pengarang dan ekologi sastra merupakan metodologi yang menghubungkan antara sastra dan lingkungan sekitarnya. Novel Bapangku Bapunkku karya Pago Hardian, bukan berisi cerita yang mengemukakan kisah yang inspiratif saja, tetapi ditulis dengan cara yang berbeda yaitu memasukkan beberapa puisi dan surat serta kutipan lirik lagu, yang sangat jarang atau tidak pernah digunakan oleh penulis yang lain. Masalah penelitian bagaimana menganalisis ekologi sastra puisi dalam novel Bapangku Bapunkku Karya Pago Hardian? Teknik pengumpulan data menggunakan dokumentasi dan teknik analisis data menggunakan teknik analisis konten. Ekologi sastra yang paling dominan digunakan pada novel Bapangku Bapunkku adalah puisi Rayuanku dan paling minim yaitu puisi Marah. Puisi yang terdapat dalam novel Bapangku Bapunkku karya Pago Hardian, terdiri dari Dahlia Ungu, Cinta Dalam Doa, Rayuanku, dan Marah.
\end{abstract}

Kata Kunci: Ekologi, Sastra, dan Bapangku Bapunkku

\section{ECOLOGICAL LITERATURE ON POETRY IN MY NOVELS OF BAPANGKU BAPUNKKU, BY HARDIAN PAGO}

\begin{abstract}
Literary works are created to be enjoyed, felt and utilized by readers or lovers of literature. Literary creation process does not escape the environment around the author and literary ecology is a methodology that connects literature and the surrounding environment. Bapangku Bapunkku's novel by Pago Hardian, does not contain a story that tells an inspirational story, but is written in a different way, which includes several poems and letters and quotes from song lyrics, which are rarely used by other writers. The research problem is how to analyze the literary ecology of poetry in the novel Bapangku Bapunkku by Pago Hardian? Data collection techniques use documentation and data analysis techniques using content analysis techniques. The most dominant literary ecology used in Bapangku Bapunkku novels is my seduction poetry and the least is Marah poetry. Poetry contained in the novel Bapangku Bapunkku by Pago Hardian, consisting of Purple Dahlia, Love in Prayer, My Flirtation, and Angry.
\end{abstract}

Keywords: Ecology, Literature, and Bapangku Bapunkku 


\section{A. PENDAHULUAN}

Sastra adalah karangan indah hasil kegiatan kreatif manusia dalam mengekspresikan pikiran dan perasaannya dalam bahasa tulis, sebagai cerminan dari suatu peristiwa yang terjadi pada kehidupan masyarakat. Pengarang menghasilkan sebuah karangan indah untuk mengungkapkan ide dan gagasannya terhadap dunia yang terjadi di sekitarnya dan mencampurkannya dengan imajinasi serta harapan dan juga nilai-nilai yang terdapat dalam proses pembuatan sastra tersebut.

Karya sastra diciptakan untuk dinikmati, dirasakan, dan dimanfaatkan oleh pembaca ataupun penikmat sastra. Suatu karya sastra tidak dapat tercipta dengan sendirinya, karena dalam proses penciptaan sastra diperlukan pengalaman hidup serta kemampuan seseorang untuk menciptakan, mengkreasikan dan merasakan berbagai peristiwa yang terjadi di sekitar kehidupan masyarakat. Hal ini serupa dengan pendapat Suhendar dan Pien Supinah (1993:6), yang mengemukakan bahwa "Karya sastra tidak tercipta oleh sembarang orang, karena penciptaan sastra bukan kegiatan yang muncul tiba-tiba. Untuk menciptakan sebuah karya sastra si pencipta memerlukan daya imajinasi yang kuat. Karya sastra terbentuk, karena proses penciptaan si pencipta mempunyai daya cipta, daya rasa dan daya karsa yang terus berlangsung dalam kehidupannya."

Proses penciptaan karya sastra tidak luput dari peran lingkungan sekitar pengarang. Pengarang menciptakan suatu karya sastra bukan hanya berdasarkan pada daya imajinasi serta pengalaman hidupnya saja, tetapi juga berdasarkan keadaan lingkungan di mana ia berada. Ekologi sastra merupakan metodologi penelitian yang mulai dilirik, karena antara sastra dan lingkungan berkaitan erat satu sama lain yang tidak dapat dipisahkan. Menurut Endraswara (2016:3), ekologi ialah ilmu yang mempelajari hubungan timbal balik antara mahluk hidup dengan lingkungannya. Atas dasar definisi ini maka ekologi sastra juga mencari hubungan timbal balik antara sastra dengan lingkungannya. Hubungan resiprokal itu penting untuk melihat keterkaitan satu sama lain. Berdasarkan penjelasan tersebut, maka peneliti mencoba menganalisis ekologi sastra yang terdapat dalam novel Bapangku Bapunkku karya Pago Hardian.

Alasan peneliti memilih novel Bapangku Bapunkku karya Pago Hardian, karena dalam novel tersebut bukan hanya berisi cerita yang mengemukakan kisah yang inspiratif saja, tetapi ditulis dengan cara yang berbeda yaitu memasukkan beberapa puisi dan surat serta kutipan lirik lagu, yang sangat jarang atau tidak pernah digunakan oleh penulis yang lain. Penulis novel ini pun menjadi pemenang II Lomba Menulis Novel Inspiratif INDIVA 2014. 
Buku karyanya telah banyak yang terbit dan beredar di pasaran lebih dari 20 judul, kebanyakan cerita tentang remaja dan anak. Penulis pun telah beberapa kali meraih juara, dalam penulisan kumpulan cerpen dan sebagainya.

Masalah yang dikemukakan dalam penelitian ini adalah bagaimana menganalisis ekologi sastra puisi dalam novel Bapangku Bapunkku Karya Pago Hardian?

Namun, penelitian ini dibatasi hanya dalam menganalisis ekologi sastra pada puisi yang terdapat pada novel Bapangku Bapunkku karya Pago Hardian, bukan keseluruhan isi novelnya. Puisi yang terdapat pada novel Bapangku Bapunkku karya Pago Hardian sebanyak empat puisi dengan judul Dahlia Ungu, Cinta Dalam Doa, Rayuanku dan Marah. Tujuan dari penelitian ini adalah untuk mengetahui dan mendeskripsikan hasil analisis ekologi sastra dalam novel Bapangku Bapunkku Karya Pago Hardian. Manfaat dalam penelitian ini dibagi menjadi dua yaitu, manfaat secara teoritis, yaitu a) memperkaya khazanah ilmu pengetahuaan di bidang kesusastraan, b) menambah khazanah pustaka agar nantinya dapat digunakan sebagai penunjang kajian sastra dan dapat dijadikan sebagai bandingan penelitian yang sejenis. Sedangkan manfaat praktis diharapkan dapat bermanfaat bagi siswa, yaitu dapat meningkatkan pemahaman dan memperoleh pengetahuan tentang ekologi yang terkandung dalam sebuah karya sastra; dan bagi pembaca bermanfaat untuk mengetahui dan menggunakan ekologi sastra dalam menganalisis karya sastra lain, khususnya pada Novel Bapangku Bapunkku Karya Pago Hardian.

\section{B. TINJAUAN PUSTAKA}

\section{Pengertian Ekologi Sastra}

Menurut Kristanto (2013:29), "Ekologi didefinisikan sebagai ilmu tentang hubungan timbal balik antar makhluk hidup (termasuk manusia) dengan lingkungannya. Oleh karena itu permasalahan lingkungan hidup pada hakikatnya adalah permasalahan ekologi.” Berdasarkan Kamus Geografi (2012:74) menjelaskan sebagai berikut.

Ekologi adalah cabang ilmu yang mempelajari interaksi antara organisme dengan lingkungannya dan yang lainnya. Ekologi diartikan sebagai ilmu yang mempelajari baik interaksi antarmakhluk hidup maupun antara makhluk hidup dan lingkungannya. Dalam ekologi, makhluk hidup dipelajari sebagai kesatuan atau sistem dengan lingkungannya. Pembahasan ekologi tidak lepas dari pembahasan ekosistem dengan berbagai komponen penyusunnya, yaitu faktor abiotik dan biotik. Faktor abiotik antara lain suhu, air, kelembapan, cahaya dan topografi, sedangkan faktor biotik adalah makhluk hidup 
terdiri dari manusia, hewan, tumbuhan, dan mikroba. Ekologi juga berhubungan erat dengan tingkatan-tingkaatan organisasi makhluk hidup, yaitu populasi, komiunitas, dan ekosistem yang saling mempengaruhi dan merupakan suatu sistem yang menunjukkan kesatuan.

Selanjutnya Endraswara (2016:2), mengemukakan bahwa ekologi merupakan gabungan dari dua kata dalam bahasa Yunani yaitu oikos berarti rumah dan logos berarti ilmu atau pelajaran. Secara etimologis ekologi berarti ilmu tentang mahluk hidup dan rumah tangganya, maka ekologi sastra juga meneliti sastra dari sisi ekologisnya. Dengan kata lain definisi ekologi ialah ilmu yang mempelajari hubungan timbal balik antara mahluk hidup dengan lingkungannya. atas dasar definisi ini maka ekologi sastra juga mencari hubungan timbal balik antara sastra dan lingkungannya. Pendapat Endraswara (2016:73) ekologi sastra adalah lingkungan (situasi dan kondisi) yang turut terlibat di panggung wacana.

Berdasarkan penjelasan beberapa teori tersebut, maka ekologi sastra merupakan suatu ilmu yang mengkaji atau meneliti teori sastra maupun kesusastraan dari segi ekologisnya, yaitu hubungan penciptaan sastra dengan lingkungan sekitarnya.

\section{Teori Kajian Ekologi Sastra}

Keadaan lingkungan alam yang mempunyai pengaruh terhadap kesastraan dan kebutuhan hidup manusia. Salah satu kebutuhan hidup manusia adalah pendidikan maupun berpendapat, mengemukakan gagasan ataupun pikiran. Jika dihubungkan dengan kesastraan, maka perubahan yang terjadi pada lingkungan alam sekitar manusia (ekologis) dapat membuat manusia berubah untuk menyesuaikan dirinya dengan berbagai macam gagasan maupun pemikirannya. Sastra merupakan karya imajinaatif yang lahir dari keadaan lingkungan masyarakat sekitar. Hal ini senada dengan pendapat Endraswara (2016:17) ekologi sastra adalah sebuah cara pandang memahami persoalan lingkungan hidup dalam perspektif sastra. Atau sebaliknya, bagaimana memahami kesastraan dalam perspektif lingkungan hidup. Ulang-alik antara lingkungan hidup (ekologi) dan sastra menjadi bidang garapan ekologi sastra. Manshur (dalam Endraswara, 2016:17), mengemukakan bahwa penelitian sastra dari studi kasus akan fokus pada kasus tertentu saja. Bila meneliti ekologi sastra, tentu kasus akan digiring ke arah hubungan sastra, manusia dan lingkungannya, sehingga penelitian ekologi sastra dapat mengangkat kasus sastra dengan lingkungan yang mengitarinya. 
Kajian ekologi sastra berupaya untuk menemukan spesifikasi lebih tepat mengenai hubungan antara kegiatan manusia dengan proses alam tertentu dalam suatu kerangka analisis ekosistem atau menekankan saling ketergantungan sebagai suatu komunitas alam. Pendekatan yang digunakan dalam menganalisis interelasi sastra dan lingkungan, dapat menggunakan wawasan pendekatan ekologi sastra. Ekologi sastra menekankan pentingnya eksploitasi kultural manusia terhadap lingkungan alam dan penyesuaian kehidupan manusia terhadap kondisi-kondisi suatu lingkungan. Kajian ekologi sastra akan mencermati proses adaptasi kultural sastra terhadap lingkungan alam dan/atau sebaliknya.

Pendekatan ekologis berusaha mencapai spesifikasi yang lebih tepat mengenai hubungan antara semua kegiatan manusia, transaksi biologis dan proses alam tertentu ke dalam satu sistem analisis yaitu ekosistem. Sastra selalu berada pada dua tataran ekosistem, yaitu (1) ekosistem terbuka, yang artinya korelasi antara sastra dan lingkungannya tampak jelas dan pasti, dapat dinyatakan sebagai karya nyata (realitas); (2) ekosistem tertutup, adalah korelasi sastra dan lingkungan yang masih perlu diraba atau ditafsirkan. Korelasi tertutup ini sebagai akibat permainan imajinatif tingkat tinggi para sastrawan (Endraswara,2016:19).

\section{METODE PENELITIAN}

Penelitian ini menggunakan metode penelitian deskriptif kualitatif. Menurut Aminuddin (1990:16), metode deskriptif kualitatif artinya menganalisis bentuk deskripsi, tidak berupa angka atau koefisien tentang hubungan antarvariabel. Metode deskriptif merupakan metode yang membicarakan beberapa kemungkinan untuk memecahkan berbagai masalah secara aktual, dengan mengumpulkan data, mengklasifikasikan dan mengeneralisasikannya, serta menganalisis dan menginterpretasikan karya.

Penelitian ini menggunakan metode deskriptif kualitatif untuk memperoleh gambaran ekologi sastra dalam novel Bapangku Bapunkku karya Pago Hardian. Pemilihan metode ini didasarkan atas pertimbangan bahwa metode ini digunakan untuk menganalisis dan menemukan ekologi sastra dalam novel Bapangku Bapunkku karya Pago Hardian.

Sumber data dalam penelitian ini adalah novel Bapangku Bapunkku yang merupakan karya Pago Hardian. Novel Bapangku Bapunkku karya Pago Hardian dicetak oleh Indiva, Solo, tahun 2015, 232 halaman, dengan ukuran buku $20 \mathrm{~cm}$.

Data dalam penelitian ini adalah data deskriptif yang berupa uraian cerita, ungkapan, pernyataan, kata-kata tertulis, dan perilaku yang diamati (Arikunto, 1993:6). Data dalam penelitian kualitatif adalah data deskriptif yang berupa kata, kalimat, dan ungkapan dalam 
setiap paragraf dalam novel Bapangku Bapunkku karya Pago Hardian, yang mengandung nilai-nilai untuk dikaji seperti hubungan ekologi dan sastra yang terdapat dalam novel.

Teknik pengumpulan data yang digunakan dalam penelitian ini adalah teknik dokumentasi. Teknik dokumentasi, yaitu mencari data mengenai hal-hal atau variabel yang berupa catatan, transkrip, buku, surat kabar, majalah, notulen rapat, legger, agenda, dan sebagainya (Arikunto, 2010:274). Menurut Sedarmayanti \& Syarifudin (2011:86), dokumen merupakan salah satu alat yang digunakan untuk mengumpulkan data dalam penelitian kualitatif. Teknik ini digunakan untuk memperoleh data ekologi, yang digunakan dalam penulisan sastra, yang terdapat dalam novel Bapangku Bapunkku karya Pago Hardian. Novel Bapangku Bapunkku karya Pago Hardian menjadi objek penelitian. Namun, pada penelitian ekologi sastra ini, objek penelitian terbatas hanya pada puisi yang terdapat dalam novel Bapangku Bapunkku karya Pago Hardian, yaitu Dahlia Ungu, Cinta Dalam Doa, Rayuanku, dan Marah.

Teknik analisis data yang akan digunakan dalam penelitian ini adalah menggunakan analisis konten. Penggunaan teknik analisis konten dilihat dari beberapa pandangan bahwa karya sastra yang bermutu adalah karya yang mampu mencerminkan pesan positif bagi pembacanya. Penggunaan teknik analisis konten digunakan agar peneliti dapat menganalisis ekologi sastra dalam novel Bapangku Bapunkku karya Pago Hardian.

Menganalisis data dilakukan dengan sunguh-sungguh, terstruktur, dan sistematis, maka hasil yang didapat akan objektif. Dalam penelitian ini untuk mencapai tujuan tersebut maka dilakukan langkah-langkah sebagai berikut.

1. Membaca novel Bapangku Bapunkku karya Pago Hardian untuk mendapatkan kesan pertama. Kemudian membaca ulang untuk mendapatkan pemahaman tentang isi novel tersebut.

2. Membuat sinopsis novel Bapangku Bapunkku karya Pago Hardian untuk mengetahui gambaran isi novel yang akan dikaji.

3. Menganalisis ekologi sastra yang terkandung dalam novel Bapangku Bapunkku, yaitu pada puisi Dahlia Ungu, Cinta Dalam Doa, Rayuanku, dan Marah.

4. Pembahasan dan menyimpulkan hasil penelitian. 


\title{
D. HASIL PENELITIAN DAN PEMBAHASAN
}

\section{Sinopsis Novel Bapangku Bapunkku Karya Pago Hardian}

Berikut ini merupakan sinopsis cerita novel Bapangku Bapunkku karya Pago Hardian.

Bapangku Bapunkku merupakan sebuah cerita keluarga Alap. Keluarga kecil yang terdiri dari Bapang, Bunda, dan keempat anaknya, yaitu Alap, Harnum, Tuah dan Anjam. Bapang merupakan sebuah panggilan Ayah dalam bahasa Semende, hal ini karena dalam keluarga Alap, seorang Ayah tidak mau dipanggil dengan panggilan Ayah tetapi Bapang. Bapang merupakan seorang Ayah yang memiliki darah biru dengan kepribadian yang keras, Islami, tetapi memiliki kebebasan dalam berpikir, berekspresi, berkarya dan berpendapat sehingga ketika pemikirannya berbeda dari pemikiran masyarakat sekitarnya, Bapang dianggap egois atau keras kepala. Namun, di luar dari kepribadian Bapang tersebut, ia merupakan orang yang cukup bersahabat, dermawan, humoris, penyayang dan baik. Cerita yang mengisahkan lika-liku kehidupan keluarga Alap dengan keunikan dan kejenakaan Bapang dan anak-anaknya, cara berpikir Bapang yang bebas dan demokratis, yang menimbulkan beberapa konflik. Dimulai dari perdebatan rencana pembelian antena televisi, sampai pemilihan acara televisi yang ditonton oleh keluarga, masalah pembangunan masjid, kepala sekolah yang diajak ribut dan yang berakhir dengan pemindahan sekolah Harnum serta anak-anaknya yang lain, sehingga berimbas terjadinya pertengkaran antara Bapang dan Bunda yang berujung perceraian hanya karena masalah pendidikan anak-anaknya, yaitu harus masuk sekolah formal seperti masyarakat umumnya atau tidak perlu lagi sekolah cukup menerima pendidikan yang informal yang dapat disesuaikan dengan kemampuan, kesukaan, keterampilan yang diminati oleh anak-anaknya.

\section{Analisis Ekologi Sastra pada Puisi dalam Novel Bapangku Bapunkku Karya Pago Hardian}

\subsection{Analisisis Ekologi Sastra Dahlia Ungu dalam Novel Bapangku Bapunkku Karya Pago Hardian}

Zaman tak pandai mengubah hati

\author{
Dahlia Ungu \\ Karya Greattole
}

Namun, usia memakan raga

Tertegun kau di depan pintu

Antara percaya dan tidak

Memeluk sahabat lama yang hilang

Setangkai dahlia ungu tertiup angin

Mengabarkan banyak cerita: cinta, duka, kegagalan, dan 
bahagia

Di bingkai jendela engkau tersenyum

Katamu, aku iri pada cita-citamu

Engkau tidak tahu, aku pun iri dengan kehidupanmu

Pondok bahagiamu menghadap ke timur

Tangisan anak lelaki pertama membangunkan pagi

Harum nasi mengepul dari dapur istrimu

Lalu, nikmat Tuhan yang mana lagi yang masih kau ingkari?

Jadi, relakan aku pergi, biar kukayuh perahuku

Aku berjuang untuk merajut cita-cita di luas samudra dan biru angkasa

Hingga suatu hari engkau berkata bangga: lihatlah!

Di lengkung pelangi sahabatku tersenyum, sinar dan pesonanya

mendamaikan hati

Kita boleh menangis

Tapi, pastikan bahwa hati kita telah bersih dari dengki

Tuhan memberikan kemuliaan yang berbeda-beda untuk setiap manusia

(Hardian, 2015:49-50)

Berdasarkan puisi tersebut, maka analisis ekologi sastra pada puisi Dahlia Ungu dalam novel Bapangku Bapunkku karya Pago Hardian sebagai berikut.

Pada puisi Dahlia Ungu pengarang menggunakan alam dan lingkungan sekitarnya sebagai penciptaan karyanya. Ekologi sastra yang digunakan oleh pengarang dapat kita lihat dari kata-kata berikut ini.

Zaman tak pandai mengubah hati, setangkai dahlia ungu tertiup angin, pondok bahagiamu menghadap ke timur, tangisan anak lelaki pertama membangunkan pagi; jadi, relakan aku pergi, biar kukayuh perahuku, Aku berjuang untuk merajut cita-cita di luas samudra dan biru angkasa, di lengkung pelangi sahabatku tersenyum, sinar dan pesonanya.

Kata-kata tersebut merupakan kata-kata yang menunjukkan kondisi atau keadaan alam dan situasi lingkungan yang terjadi mempengaruhi si pengarang. Penggunaan kata-kata zaman, setangkai dahlia ungu tertiup angin, menghadap ke timur, membangunkan pagi, kukayuh perahuku, luas samudra dan biru angkasa, di lengkung pelangi, sinar, merupakan bagian dari ekologi yang menunjukkan keadaan waktu, kondisi dan lingkungan alam sekitar. Ekologi yang terwujud dalam suatu karya sastra karena hasil cipta, rasa, karsa pengarang dalam memilah dan memilih diksi yang tepat sehingga menciptakan makna yang mendalam dan indah. Pendekatan ekologis yang digunakan dalam puisi tersebut menggunakan dua tataran sekaligus, yaitu tataran ekosistem terbuka dan ekosistem tertutup. 


\subsection{Analisisis Ekologi Sastra Cinta Dalam Doa dalam Novel Bapangku Bapunkku Karya Pago Hardian}

\section{Cinta Dalam Doa}

Diam kuraba kelamnya malam

Puisi dari Wulandari untuk Alap Nian

Merajut dawai impian

Beruntai kata kiasan

Berucap harap cinta dalam kesepian

Biarlah rinduku berlayar

Di biduk larut peraduan

Bila masa yang kunantikan tiba

Singgah membawa harapan

Jadikan indah sebuah ikatan

Maka, sempurnalah sudah segala gundah

Semoga Tuhan mengabulkan

Segala pinta semua doa

Untuk mendapatkanmu

Pelangi dambaan jiwaku

(Hardian, 2015:72-73)

Berdasarkan puisi tersebut, maka analisis ekologi sastra pada puisi Cinta Dalam Doa dalam novel Bapangku Bapunkku karya Pago Hardian sebagai berikut.

Pada puisi Cinta Dalam Doa pengarang menggunakan alam dan lingkungan sekitarnya sebagai penciptaan karyanya. Ekologi sastra yang digunakan oleh pengarang dapat kita lihat dari kata-kata berikut ini.

Diam kuraba kelamnya malam, berucap harap cinta dalam kesepian, biarlah rinduku berlayar, di biduk larut peraduan, pelangi dambaan jiwaku. Kata-kata tersebut merupakan kata-kata yang menunjukkan kondisi atau keadaan alam dan situasi lingkungan yang terjadi pada si pengarang. Penggunaan kata-kata kelamnya malam, kesepian, berlayar, larut peraduan, dan pelangi merupakan bagian dari ekologi yang terwujud dalam suatu karya sastra karena hasil cipta, rasa, karsa pengarang dalam memilah dan memilih diksi yang tepat sehingga menciptakan makna yang mendalam dan indah. Pendekatan ekologis yang digunakan dalam puisi tersebut menggunakan satu tataran ekosistem, yaitu ekosistem tertutup, yang artinya korelasi sastra dan lingkungan yang masih harus diraba atau ditafsirkan. 


\title{
2.3 Analisis Ekologi Sastra Rayuanku dalam Novel Bapangku Bapunkku Karya Pago
}

\section{Hardian}

\author{
Rayuanku \\ Puisi dari Paguh untuk Fatonah \\ Kau umpama bintang di langit \\ Kemilau hiasi bumi \\ Kau ibarat pasir berserak \\ Memutih indah di Pantai Kuta \\ Kilaumu bercahaya \\ Berpijar bagai surya \\ Bertabur laksana bintang \\ Bersinar bak rembulan \\ Senyummu bingkai jiwaku \\ Kedipmu lambungkan angan \\ Tatapanmu bius hatiku \\ Suaramu \\ Gayamu \\ Bibirmu \\ Dandananmu \\ Semuanya!!! \\ Kalau kau menolak \\ Bunuh saja aku!!!
}

(Hardian, 2015:77-78)

Berdasarkan puisi tersebut, maka analisis ekologi sastra pada puisi Rayuanku dalam novel Bapangku Bapunkku karya Pago Hardian sebagai berikut.

Pada puisi Rayuanku pengarang menggunakan alam sebagai penciptaan karyanya. Ekologi sastra yang digunakan oleh pengarang dapat kita lihat dari kata-kata berikut ini.

Kau umpama bintang di langit, kemilau hiasi bumi, ibarat pasir berserak, pantai Kuta, berpijar bagai surya, bertabur laksana bintang, bersinar bak rembulan. umpama bintang di langit, kemilau hiasi bumi, berpijar bagai surya, bertabur laksana bintang, bersinar bak rembulan merupakan kata-kata yang mengungkapkan keindahan cahaya dan kemilau dari alam semesta. Surya, langit, bumi, bintang dan rembulan bagian dari semesta yang dikaji dalam kosmologi. Berdasarkan KBBI (2016:267), mendefinisikan bahwa kosmologi adalah 1. cabang astronomi yang menyelidiki asal-usul, struktur, dan hubungan ruang waktu dari alam semesta; 2. Ilmu tentang asal-usul kejadian bumi, hubungannya dengan sistem matahari dengan jagat raya; 3. Cabang dari metafisika yang menyelidiki alam semesta sebagai sistem yang beraturan.

Namun, dalam penciptaan karya sastra ini benda-benda alam semesta yang terdapat pada kosmologi tersebut menjadi sebuah ungkapan rasa kekaguman seorang pria terhadap 
keindahan maupun kecantikan seorang wanita. Penggunaan kata-kata surya, langit, bumi, bintang dan rembulan merupakan bagian dari ekologi yang terwujud dalam suatu karya sastra karena hasil cipta, rasa, karsa pengarang dalam memilah dan memilih diksi yang tepat sehingga menciptakan makna yang mendalam dan indah, sedangkan kata-kata ibarat pasir berserak dan pantai Kuta merupakan kata-kata yang menunjukkan atau menggambarkan kondisi suatu tempat atau wilayah lingkungan. Pendekatan ekologis yang digunakan dalam puisi tersebut menggunakan dua tataran sekaligus, yaitu tataran ekosistem terbuka dan ekosistem tertutup.

\title{
2.4 Analisis Ekologi Sastra Marah dalam Novel Bapangku Bapunkku Karya Pago Hardian
}

\author{
Marah \\ Puisi dari Paguh untuk Fatonah \\ Selamat bertemu rindu \\ Selamat datang sayang \\ Sampai jumpa cinta \\ Selamat pagi iri \\ Aku marah \\ Aku membenci semua kepalsuanmu \\ Ugh! \\ Pecah \\ Lebur \\ Sembilu \\ Belenggu \\ Jerat-jerat \\ Jadilah abu
}

(Hardian, 2015:78-79)

Berdasarkan puisi tersebut, maka analisis ekologi sastra pada puisi Marah dalam novel Bapangku Bapunkku karya Pago Hardian sebagai berikut.

Pada puisi Marah pengarang menggunakan alam maupun lingkungan sebagai penciptaan karyanya. Ekologi sastra digunakan oleh pengarang dalam puisi ini adalah selamat pagi iri. Kata-kata ini menunjukkan keadaan waktu yang terjadi. Pagi merupakan kondisi alam yang terjadi karena adanya rotasi bumi yang mengelilingi matahari sehingga terjadi perubahan waktu siang dan malam. Pagi merupakan kondisi waktu yang dimulai dari terbitnya matahari di ufuk timur sampai matahari meninggi di atas kepala yaitu sekitar jam 06.00-12.00. Bila dihubungkan ke dalam sastra, maka selamat pagi iri adalah suatu kondisi di mana pengarang lebih awal merasakan sifat iri atau sifat iri yang muncul terlalu dini tanpa 
sebab. Pendekatan ekologis yang digunakan dalam puisi tersebut menggunakan satu tataran ekosistem, yaitu ekosistem tertutup.

\section{Pembahasan Hasil Analisis Ekologis Sastra}

Hasil analisis ekologis sastra dalam novel Bapangku Bapunkku karya Pago Hardian, pada puisi Dahlia Ungu, Cinta dalam Doa, Rayuanku dan Marah adalah sebagai berikut.

Pada puisi Dahlia Ungu dalam novel Bapangku Bapunkku karya Pago Hardian, menunjukkan kondisi alam mempengaruhi pengarang dalam menciptakan karya sastranya, seperti pada kata-kata: zaman tak pandai mengubah hati, setangkai dahlia ungu tertiup angin, pondok bahagiamu menghadap ke timur, tangisan anak lelaki pertama membangunkan pagi; jadi, relakan aku pergi, biar kukayuh perahuku, Aku berjuang untuk merajut cita-cita di luas samudra dan biru angkasa, di lengkung pelangi sahabatku tersenyum, sinar dan pesonanya. Kata-kata yang berhubungan dengan alam atau lingkungan adalah kata 'zaman' yang merupakan bagian dari alam yang menunjukkan arti jangka waktu yang panjang atau pendek yang menandai sesuatu; kala atau waktu. Kata setangkai dahlia ungu tertiup angin, kata 'pondok' yang artinya bangunan untuk tempat sementara; rumah; bangunan tempat tinggal berpetak-petak; madrasah atau asrama. Kata 'timur' artinya mata angin yang arahnya berlawanan dengan barat; orang atau bangsa dari benua di bagian timur; blok timur. Kata 'pagi' artinya bagian awal dari hari; waktu setelah matahari terbit hingga menjelang siang hari; awal atau cepat. Kata luas samudra dan biru angkasa, dan kata 'pelangi' artinya lengkung spektrum warna di langit, tampak karena pembiasan sinar matahari oleh titik-titik hujan atau embun; bianglala; warna yang beraneka macam; kain atau selendang yang bermacam-macam warnanya. Maknanya akan mengalami perubahan ketika alam dan manusia tercipta ke dalam sastra. Seperti kata pondok bahagiamu menghadap ke timur yang memiliki arti kebahagiaannya telah teralihkan atau tempat yang selama ini ia rasakan bahagia telah berubah.

Pada puisi Cinta Dalam Doa dalam novel Bapangku Bapunkku karya Pago Hardian, menunjukkan keadaan alam dan situasi lingkungan yang terjadi pada si pengarang. Hal ini terlihat pada kata-kata: diam kuraba kelamnya malam, berucap harap cinta dalam kesepian, biarlah rinduku berlayar, di biduk larut peraduan, pelangi dambaan jiwaku. Kata-kata tersebut memiliki proses kreatif yang menggabungkan alam dan manusia. Kata diam kuraba kelamnya malam memiliki makna secara diam-diam atau sembunyi-sembunyi menyelidiki, gelapnya dunia/ gelapnya (kelamnya) malam hari. Diam kuraba kelamnya malam merupakan 
dua kata gabungan antara gerakan manusia dan alam yaitu diam dan kuraba adalah gerakan yang hanya bisa dilakukan manusia sedangkan alam mewujud dalam kata kelam dan malam yaitu kondisi waktu. Begitu juga dengan kata-kata seperti berucap harap cinta dalam kesepian, biarlah rinduku berlayar, di biduk larut peraduan, pelangi dambaan jiwaku, merupakan gabungan antara alam atau lingkungan dan manusia. Di mana alam bertindak seperti manusia atau sebaliknya manusia bertindak seperti alam.

Pada puisi Rayuanku dalam novel Bapangku Bapunkku karya Pago Hardian, menunjukkan bahwa ada keterkaitan penciptaan sastra dengan lingkungan yang ada, yaitu penggunaan ilmu kosmologis seperti kata-kata berikut: Kau umpama bintang di langit, kemilau hiasi bumi, berpijar bagai surya, bertabur laksana bintang, bersinar bak rembulan. Ilmu kosmologis digunakan di dalam sastra yaitu penggunaan tataran benda-benda yang berhubungan dengan sistem matahari atau tata surya yaitu bintang, langit, bumi, surya dan rembulan. Berdasarkan Kosmografi (2014:53), menjelaskan bahwa bintang adalah benda langit yang memancarkan cahaya dan panasnya sendiri, sedangkan berdasarkan KBBI (2016:89), menjelaskan bintang adalah benda langit terdiri atas gas menyala seperti matahari, terutama tampak pada malam hari; 2. Planet atau gugusan planet yang menjadi pegangan dalam astrologi untuk menentukan nasib seseorang; 3. Nasib; peruntungan; untung malang; 4. Tanda jasa yang berupa mendali emas; 5. Tanda pangkat perwira militer berbentuk seperti bintang; 6. Tanda yang menyerupai bintang, seperti tanda (*); 7. Pemain yang terkemuka (dalam film, sandiwara); 8. Orang yang terbaik (terpandai dalam suatu lingkungan). Kosmografi tidak menjelaskan mengenai definisi langit, tetapi dari halaman 394-403 menjelaskan mengenai tata koordinat langit. Sedangkan KBBI mendefinisikan langit adalah ruang luas terbentang di atas bumi, tempat beradanya bulan, bintang, matahari dan planet yang lain. Berdasarkan Kosmografi (2014:251), menjelaskan bahwa bumi adalah sebuah benda langit seperti matahari, bulan dan bintang-bintang. Keberadaan bumi di jagat raya tidak berdiri sendiri serta bebas, tetapi bersama-sama serta berhubungan dengan benda-benda langit yang lain dipengaruhi/ditentukan oleh hukum-hukum berlaku di jagat raya. Matahari dan bulan besar pengaruhnya terhadap bumi. Sedangkan menurut KBBI, bumi adalah 1 . Planet tempat manusia hidup; dunia; jagat; 2. Planet ke-3 dari matahari; 3. Permukaan dunia; tanah. Berdasarkan Buku Kosmografi (2014:140), menjelaskan matahari adalah pusat dan induk tata surya. Benda langit bintang sejati. Sedangkan KBBI, menjelaskan bahwa surya adalah matahari ialah benda angkasa, titik pusat tata surya berupa pola berisi gas yang mendatangkan terang dan panas pada bumi di siang hari. Berdasarkan KBBI, bulan adalah 1. 
Benda langit yang mengitari bumi, bersinar pada malam hari karena pantulan sinar matahari; 2. Masa atau jangka waktu perputaran bulan mengitari bumi dari mulai tampaknya bulan sampai hilang kembali (29 atau 30 hari). Sedangkan berdasarkan Kosmografi dari halaman 339-389 tidak ada definisi yang menjelaskan mengenai bulan, tetapi menjelaskan mengenai sejarah, sifat fisik, peredaran, fase, orbit dan librasi bulan.

Berdasarkan pembahasan mengenai arti kata, maka berikut ini merupakan pembahasan mengenai gabungan kata-kata antara benda-benda langit atau lingkungan sekitar dengan kata-kata berwujud sastra, seperti Umpama bintang di langit menggambarkan wanita pujaannya ibarat bintang yang ada di langit yang sulit tuk digapai, kemilau hiasi bumi menggambarkan pesona wanita pujaannya tersebut telah menghiasi kehidupannya (sang pria/pengarang), berpijar bagai surya menggambarkan bahwa sang wanita pujaan tersebut memiliki kepribadian yang sangat hangat, baik kepada siapa saja walau terkadang sedikit galak, bertabur laksana bintang menggambarkan sang wanita pujaan hati memiliki berbagai perhiasan (memiliki materi), bersinar bak rembulan menggambarkan bahwa sang pujaan hati walau berlimpah materi tetap rendah hati. Pengungkapan makna sastra melalui ekologi sastra dianggap mampu menjelaskan bahwa sastra merupakan hasil kreatif alam dan manusia merupakan bagian yang tidak terpisahkan. Hal ini serupa dengan pernyataan Endraswara (2016:89), "Pengungkapan makna sastra secara ekokritik dianggap mampu menjelaskan bahwa sastra merupakan produk kreatif alam di mana manusia menjadi bagian yang tidak terpisahkan di dalamnya".

Pada puisi Marah dalam novel Bapangku Bapunkku karya Pago Hardian, menunjukkan bahwa selamat pagi iri, merupakan bagian dari alam atau lingkungan sekitar dan proses kreatif yang dilakukan pengarang, yang menjelma menjadi sastra. Antara Alam dan manusia yang berada di lingkungan sekitar pengarang terwujud menjadi kata selamat pagi iri, menunjukkan suatu keadaan waktu yang terjadi pada diri/sifat manusia. Kata 'selamat' artinya terbebas dari bahaya; sehat; tercapainya maksud; doa; pemberian salam mudah-mudahan dalam keadaan baik. Kata 'pagi' artinya bagian awal dari hari; waktu setelah matahari terbit hingga menjelang siang hari. Kata 'iri' memiliki arti merasa kurang senang dengan kelebihan orang lain; cemburu; sirik; dengki.

\section{E. Kesimpulan dan Saran}

Berdasarkan hasil temuan analisis dan pembahasan ekologi sastra pada puisi dalam novel Bapangku Bapunkku karya Pago Hardian, maka dapat disimpulkan sebagai berikut. 
Pada puisi yang terdapat dalam novel Bapangku Bapunkku karya Pago Hardian, yaitu Dahlia Ungu, Cinta Dalam Doa, Rayuanku, dan Marah. Ekologi sastra yang dominan digunakan terdapat pada puisi Rayuanku yaitu banyak ditemukannya tataran tata surya yang digunakan dalam pembuatan puisi dan penunjukkan tempat atau wilayah. Paling sedikit menggunakan alam atau ekologi dalam sastra terdapat pada puisi Marah, pada puisi hanya terdapat satu kata yang menunjukkan penggunaan alam, lingkungan atau ekologi yaitu kata pagi. Sedangkan pada puisi Dahlia Ungu dan Cinta Dalam Doa menunjukkan bahwa pengarang masih menggunakan alam, lingkungan dan hubungan ekologi di dalam penciptaan sastranya, walaupun tidak sedominan pada puisi Rayuanku.

\section{DAFTAR PUSTAKA}

Aminuddin. 1990. Karateristik Penelitian Kualitatif. Malang: Hiski Komisariat Malang dan YA3.

Arikunto, Suharsimi. 1993. Prosedur Penelitian Suatu Praktek. Bandung: Rineka Cipta.

Arikunto, Suharsimi. 2010. Prosedur Penelitian: Suatu Pendekatan Praktis. Jakarta: Rineka Cipta.

Endarto, Danang.2014. Kosmografi. Yogyakarta: Ombak

Endraswara, Suwardi. 2016. Metodologi Penelitian Ekologi Sastra; Konsep, Langkah dan Penerapan. Jakarta: PT Buku Seru.

Hardian, Pago.2015. Bapangku Bapunkku. Solo: Indiva

Kristanto, Philip. 2013. Ekologi Industri. Yogyakarta: Andi Offset.

Melati, Ratna Rima dan Eko Sujatmiko. 2012. Kamus Geografi. Surakarta: Aksara Sinergi Media.

Suharso dan Ana Retnoningsih. 2016. Kamus Besar Bahasa Indonesia Edisi Lux. Semarang: Widya Karya.

Suhendar \& Pien Supinah. 1995. Pendekatan Teori Sejarah \& Apresiasi Sastra Indonesia. Bandung: Pionir Jaya.

Sedarmayanti \& Syarifudin Hidayat.2011. Metodologi Penelitian. Bandung: CV. Mandar Maju. 